\title{
Measles Virus
}

National Cancer Institute

\section{Source}

National Cancer Institute. Measles Virus. NCI Thesaurus. Code C14237.

A morbillivirus that causes the childhood disease measles and is responsible for subacute sclerosing panencephalitis. 